\title{
TOWARD AN UNDERSTANDING of e- MARKETING ATTITUDES IN TURKISH AND GREEK SMES AGAINST GLOBAL COMPETITION
}

\author{
Sima NART \\ Hüseyin A. KANIBIR \\ Bal1kesir University, Turkey
}

\begin{abstract}
Supported by the growth of communication technology based on the internet, e-marketing attracts an increasing attention in global marketplace. Marketing through internet is especially important for SMEs that have operated with major difficulties due to lack of resources. The purpose of this study is to examine the attitudes of SMEs towards e-marketing, and possible determinants on their attitudes such as entrepreneurial vision and marketing philosophy. This study is based on a cross-cultural research conducted in Turkey and Greece, simultaneously. The data were collected from 116 Turkish and 82 Greek SMEs. A conceptual model is proposed with seven postulated hypotheses and verified by empirical data.
\end{abstract}

Key Words: e-marketing, SMEs, marketing philosophy

\section{INTRODUCTION}

The pressure of global competition forces all types of business, regardless of their size, to explore new markets and new ways of doing market operations. All players in the market face the risk of get weak in their positions due to devastating effect of intensive competition. Larger businesses are known to have several capabilities as financial, technical, expertise in order to take measure against competitors' attacks. However, small and medium sized enterprises (SMEs) must confront this challenge in severe limitations and with lack of resources. Competitive market environment dictates that SMEs should develop their competencies for marketing as well as production standards. It is essential to note that marketing competency is an antecedent to activate production processes. Such a capability can result in new customers from both foreign and domestic markets. In this context, the questions appear as to what marketing capabilities in hand can be improved and which options are available to develop new ones?

Existing methods and advantages should be revised continuously in order to sustain them in turbulent environment of market. Beyond this, the capability to develop new sources of competitive advantages will determine prospective positions of SMEs in the marketplace as well as larger business. SMEs have been often described as feeble and frail players due to their important managerial and financial limitations (Drew, 2003; Chaston, 2001; Webb and Sayer, 1998). In the process of pursuit the new ways of doing business, therefore, SMEs need to use more carefully the limited resources confining their capabilities. On 
the other hand, brand-new technologies seem to transform the traditional ways of doing business. The internet phenomenon represents one of the greatest advances in the history of humanity. It directly influences the way of thinking and behaviors of people through its specific advantages for lasting and effective communication. The internet-specific advantages can also be employed by businesses since communication is at the heart of marketing management as an antecedent to persuading customers.

While the internet has become a major event in the world, businesses can use it as an instrument for market activities. The international market, especially, will no longer be the area of only larger businesses if SMEs adapt the advantages of the internet into their processes. The internet introduces SMEs to global opportunities by creating an ability to announce their names, brands and products to much broader market areas. This option seems to be consistent with the need of SMEs to utilize their inadequate resources carefully. It is not, otherwise, affordable to reach wider markets for SMEs both in domestic and international context, and to design special promotion programs to persuade consumers. Web-based marketing activities, shortly e-marketing, via internet offer an obvious capability for this type of business working with limited managerial and financial resources to meet new opportunities for profitable growth.

It is therefore worthwhile to understand the extent to which the entrepreneurship vision and marketing philosophy are determinant on e-marketing strategy of businesses especially in the SMEs where such strategy is typically harder to realize than in larger businsesses. In particular it is important to examine how these variables are functional in employing the internet as a marketing instrument by SMEs. While we recognize the critical importance of marketing competency for SMEs, we examine the existence of strategic focus in SMEs' viewpoints towards emarketing as an innovative strategy. The main emphasis of this study is on the attitudes and behaviors of SMEs directed at e-marketing in relation to their marketing operations. To this end, their vision and marketing philosophies were examined as the influential factors at the background of their evaluations and behaviors. In so doing, a theoretical frame for this study is based on the effects of entrepreneurship vision and marketing philosophy in order to explain the attitudes and behaviors of SMEs in a competitive environment. While studies have considered how SMEs acted in response to the internet phenomenon as a business process such as e-commerce, few studies have considered why these firms approach the option of e- marketing as they do. In responding to this gap, this study tries to develop the model of more basic concepts that motivate the use of e-marketing strategy.

\section{LITERATURE REVIEW AND DEVELOPMENT OF HYPOTHESES}

A vast body of knowledge exists on the characteristics, activities and performances of SMEs in terms of different aspects such as management, finance, $R \& D$, and marketing. In marketing literature, studies have proposed that the owners or top managers of SMEs need to be aware of the factors generating competitiveness to them, and search for what options are available in order to build a competitive firm against larger-sized competitors (Menon and Varadarajan, 1992). The movement of globalization and improvements in communication technologies create new opportunities for all types of firms. Intensive competition, the most leading feature of today's markets, forces market players to announce themselves to target people in more effective ways. Communication ability and its effectiveness are core for firms in building a distinctive position in the minds of customers especially. As a new communication platform, the internet provides for firms the possibility to announce to and introduce millions of customers easily since "...the internet's core advantage lies in its great capacity of fast, efficient, integrated, and interactive exchange of information" (Avlonitis and Karayanni, 2000: 441). More specifically, the internet brings an economical way of contacting and attracting customers all around the world, and offers new markets by removing the traditional entry barriers (OECD, 1998). Through adopting the internet into traditional business processes firms can conduct marketing research more efficiently, serve customers better and distribute products faster (Honeycutt, Fluherty and Benassi, 1998). However, the adoption of the internet appears limited in SMEs compared to larger firms although it offers many competitive advantages. According to OECD (1998), decision-makers of SMEs are generally unfamiliar with the internet and its potential functions for market operations. Using the internet and the World Wide Web (www) in business courses of action have emerged new concepts that have been used widely as e-commerce and e-marketing. Ngai and Wat (2002) define e-commerce as a process of buying and selling the offerings using electronic data transmission via the internet and the www. It should be noted that e-commerce is transactional in nature (Krishnamurthy, 2006) whereas e-marketing refers to the use of the internet primarily for publicity 
and announcement through flowing detailed information about the firm and its offerings, and thus for building demand (Fortin, Dholakia and Dholakia, 2002; Krishnamurthy, 2006).

SMEs are visible part of entrepreneurial spirit exhibiting the thinking ways of the owners and top managers. By definition, entrepreneurship requires being courage, and courageness also entails an ability to see and comment the photograph as a whole. This ability can be called as vision (Strange and Mumford, 2005). In the literature, vision has been defined as "what you want to create of yourself and the world around you" (Senge, 1990:211). In general, there is a consensus among leading authors such as Senge (1990), Covey (2004) that vision means having a long view to the conditions for the present and future. It shapes the purposes and creates a mental picture to walk in a way (Bird and Brush, 2003).

Vision, by its own nature, has a power to help organizations as well as individuals achieve something, and also can arouse the organizations to develop their own ways of solutions. SMEs operating with important limitations have faced more difficult environment due to intensified competition in all markets. They have to overcome the problems both coming from their specific limitations and from competition in order to have competitive identity. It is a requirement to have a broader viewpoint related to environmental conditions in present and future. This means that market players should have a comprehensive understanding with the ability to predict market environment of the future, and what features will be needed for competitiveness in the future. The vision of SME, therefore, can be a significant determinant on behaviors of SMEs and on the identity an SME aims. Vision of SMEs means the vision of owners or top managers of SMEs because of their strong influence on the organization. Therefore, vision in the context of SMEs can be assessed as entrepreneurial vision. Entrepreneurial vision is associated with the evaluations about new markets, new technologies, process improvements, competition, and its potential direction (Lieberman and Montgomery, 1988). What is essential is to recognize that entrepreneurial vision is related to precognition for future, the potential problems and the ways to approach to the problems and opportunities in the near and far future.

Specific behaviors of SMEs in the process of perception to market opportunities, threats and problems, and their responses reflect directly the thinking ways of the firms towards market dynamics. This also makes marketing philosophy a current issue. A number approaches have been posited for explaining firms' marketing philosophies (Morgan, 1996; Kimery and Rinehart, 1998; Bartels, 1998; Tosun, Okumus and Fyall, 2008). Marketing literature emphasizes the nature of marketing philosophy by proposing the typologies of focus points revealed by firms (Lamb, Hair and McDaniel, 2004). A review of the literature indicates that as the socio-cultural level of consumers and technology improve, marketing thought takes form by giving importance to various attentions such as manufacturing, product, selling, and customer. Each attention area with its own specific focus is described as marketing philosophy. Firms' perceptible marketing activities, therefore, include a philosophy towards the concepts of consumer, competition, and competitiveness to achieve organization's goals. More specifically, based on different thinking ways some firms may consider a specific market event as important whereas some others view it as unimportant. In this regard, marketing activities are visible parts of a philosophy that maneuvers the allocation of resources and formulation of strategies for an organization (Kohli and Javorski, 1990). A widely accepted view in marketing literature namely market orientation states the importance of organization-wide marketing approach (Kohli and Javorski, 1990; Narver and Slater, 1990; Slater and Narver, 1994) to struggle in competitive environment. According to this, the primacy of customers is the core in determining specific marketing strategies. This view requires developing competitive strategies in order to persuade consumers against competitors. In this context it is essential to build close relationships with them and announce continuously the name of the firm to market. Thus, the activities of contacting, announcement, explanation, and reminding are emphasized as the core dimensions of market orientation in avioiding threats and taking opportunities.

Like Covey (2004) and Bird and Brush (2003) we suggest that the different values and viewpoints of decision-makers who are generally the owners or top managers in SMEs may be characterized by the concept of vision. Since it is very complicated to describe and measure a complete vision, we propose a concentration on one specific aspect that is related to marketing operations and attitudes towards e-marketing option specifically as a type of marketing strategy. Researchers studying vision emphasize that the way of view to the happenings determines the comments about the environment and thus the activities being designed (Strange and Mumford, 2005; Brush, 2008). More specifically, the way to see the facts in the environment can be expected to influence the thinking ways of any individual about them. Moreover, according to Davis (1989) and many other researchers (Adams, Nelson, 
Todd, 1992; Hendrickson, Massey and Cronan, 1993; Subramanian, 1998) perceptions on 'ease of use' and 'usefulness' are leading factors determining the direction of attitude in positive or negative way, as suggested in a specific model namely Technology Acceptance Model (TAM). We explore the effect of vision on marketing philosophy which we expect to be particularly relevant for understanding e-marketing attitudes of SMEs. Therefore, we suggest that:

H1: Marketing philosophy of SMEs is positively related to their entrepreneurial vision. That is, as the entrepreneurial vision of SMEs becomes broader so does the marketing philosophy.

H2: SMEs' perceived usefulness of e-marketing is positively related to their entrepreneurial vision. That is, as entrepreneurial vision of SMEs becomes broader so does perceived usefulnes of emarketing.

H3: SMEs' perceived ease of use of e-marketing is positively related to their marketing philosophy. That is, as their marketing philosophy incline towards market-orientation so does perceived ease of use positively by SMEs.

Understanding the essential determinants of behavior has been a supreme aim for many academicians and practitioners in social sciences. The underlying psychological postulation driving the connection between internal/psychological processes and behavior is that most human behavior is under volitional control (Ryan, 1970). This study, therefore, needs to involve an attitudinal dimension in the attempt to understand the behaviors of policymakers of SMEs towards emarketing. In other words, it is important to know SMEs' attitudes toward e-marketing in order to understand their e-marketing activities. Attitude to emarketing reflects the belief of executives in SMEs towards the ability of e-marketing process to solve the firm's market problems or generate new opportunities (Bredahl, 2001). In behavioral science literature (Ajzen and Fishbein,1980; Wilkie, 1994; Grunert et al. 2003) attitudes are accepted as something stemming from beliefs that individuals hold about an object or a phenomenon. A widely accepted theory for the formation of attitude is the model developed by Fishbein (1963), known as Fishbein Multi-attribute Model. According to this view, an attribute towards an object or a phenomenon will occur as a result of knowledge and comprehension about that object. Attitudes can be seen as positive or negative tendencies. It should be noted that attitude does not depend only on one specific belief but on a handful of them (Costa-Font et al., 2008).
Since attitude signifies a learned predisposition to respond to an incident or object (Lee, 2007), it will be affected by viewpoints to and thinking ways about happenings. In other words, whether to have a broader perspective or not can determine the form of evaluations and beliefs about a specific phenomenon or object. Similarly, the way of thinking an individual has can be able to change perceptions, and thus the direction of evaluations and beliefs from negative to positive. Based on the above reasoning we propose that:

H4: The attitude of SMEs towards e-marketing is positively related to their entrepreneurial vision. That is, as the entrepreneurial vision of SMEs increase positively so does the attitude.

H5: The attitude of SMEs towards e-marketing is positively related to their marketing philosophy. That is, as the marketing philosophy of SMEs turns to market orientation so does the attitude towards e-marketing more positive.

H6: SMEs' perceived ease of use of e-marketing has a positive effect on the attitude towards emarketing.

H7: SMEs' perceived usefulness has a positive effect on the attitude towards e-marketing.

From a theoretical point of view we benefited from a conceptual model known as 'technology acceptance model (TAM), with some modifications, developed by Davis (1989) as a part of the research model of this study examining the attitudes towards e-marketing and the influential factors on attitude. The construct of perceived usefulness (PU) and perceived ease of use (PEU) were adopted from TAM. Based on our hypotheses, the research model of this study is provided in Fig. 1.

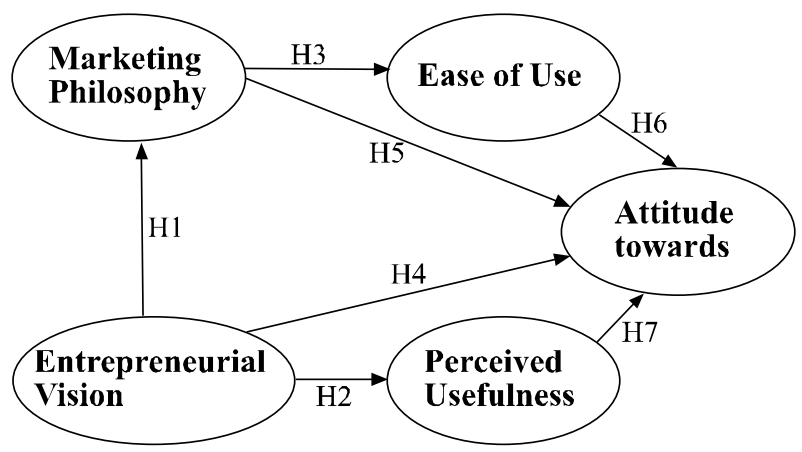

Figure 1. Research Model of the Study: 


\section{RESEARCH METHODOLOGY \\ The Measuring Instrument}

Data on SMEs' attitude towards e-marketing are not available from published sources. Therefore, based on extant literature, we generated a questionnaire to measure our constructs. The questionnaire, in four sections, was designed to measure Turkish and Greek SMEs' attitudes towards e-marketing, their entrepreneurial vision, marketing philosophy, and perceptions on usefulness and ease of use. The first part involved basic demographic and background data on the informants. This section comprised 7 questions in total. The second part was based on vision and philosophy questioning with 16 items. The third component of the instrument involved 13 items on perceived usefulness and perceived ease of use towards e-marketing. A five-point Likert type scale (strongly agree/strongly disagree) was used in the second and third parts. The reason for using a Likert-type scale was that, the vision, philosophy and perceptions are multidimensional. The fourth part was on the attitudes of SMEs with 6 items using a seven-point semantic bi-polar item (e.g. reliable-not reliable, useful-not useful, profitable-not profitable, necessary-not necessary, convincing-not convincing, conveniencenot convenience) developed by authors through adaptation from Stayman and Batra (1991). The reliability of measure in the proposed model was tested. Cronbach's alpha was used as an internal consistency measure (Hair, 2000). Cronbach's alpha for all items and the coefficient of all the indicators together are greater than 0.87 . This suggests that the scale scores are highly reliable.

\section{The Sample and Procedures}

The population for this study consisted of all the SMEs located in Turkey and Greece. Turkey and Greece are neighbouring countries with relatively similar sociocultures. However, Greece is a member of the European Union whereas Turkey endeavors to be a member. It is known that the EU gives a special attention to SMEs in order to make them more competitive. To this end, the EU designs particular programs such as education and concultancy. In this study, therefore, the SMEs in the two neighboring countries were regarded as investigation area. Since the population of the study too large, we used probability sampling in order to access to data. In Turkey, the region of Bursa was selected as the field of survey due to its feature to be a leading area of SMEs in Turkey. KOSGEB that has been working since 1990 for the development of
Turkish SMEs was the main contributor of this research to conduct a survey. In Greece, enterprises employing 50 persons and below form about $99,55 \%$ of the total number of enterprises and they employ $74 \%$ of the work force of the private sector (http://www.eommex.gr). Through EOMMEX that is a non-profit, public organization operating under the auspices of the Greek Ministry of Development for more than 30 years on the development of Greek SMEs, the SMEs located in Athens were reached.

In quantitative research, in order to minimize the sampling error and maximize the accuracy of the survey the sample should be larger (Lewis, 1984). The literature shows the state of a positive relationship between the number of items and the sample size, representing a ratio of at least 1:4 or 1:5 (Tinsley \& Tinsley, 1987; Hinkin, Tracey, \& Enz, 1997). Therefore, the sample population for each group was aimed at a total sample size of 384 which permits an allowable error rate less than $5 \%$ at the $95 \%$ confidence level. Prior studies based on data collected from SMEs reported some important problems with very low response rates (Merit, 1998) and the difficulties of respondents in interpreting the questions (Smith and Kemp, 1998). Consequently, we distributed 700 selfadministered questionnaires with close-ended questions in each country. In order to implement the survey in Greece, the form of questionnaire was written in English and translated to Greek, and controlled through 'back translation' method.

The collected data were analyzed by employing the Statistical Package for the Social Sciences (SPSS) computer program. First, a series of independent ttests were used to determine if differences existed between Turkish and Grek SMEs' entreprenurial vision, marketing philosophy, and attitudes towards emarketing. Second, regression analysis was used to measure the validity of the research model developed in this study that estimates the unique effect of entrepreneurial vision, marketing philosophy, and perceptions on SMEs' attitude towards e-marketing.

\section{Demographic Characteristics of the Sample}

In total, 209 usable questionnaires were collected from the owners or top managers of SMEs over the period of four weeks in April 2008 in Turkey and Greece. Response rate was $14.9 \%$. Of those returned, eleven questionnaires were eliminated $(5.2 \%)$. These questionnaires were incomplete or had an excessive amount of missing data. After elimination, 198 questionnaires were coded for data analysis. The 
distribution of questionnaires analyzed by nationality is as follows: Turkish SMEs $116(58.6 \%)$ and Greek SMEs $82(41.4 \%)$. The data were collected from 137 manufacturing $(69.2 \%)$ and $61(30.8 \%)$ commerce firms as total. In two age groups (less than 10 years old, and 20 years and over) there were $61.1 \%$ (121 firms) and $38.9 \%$ (77 firms) of the sampled firms, respectively. In terms of total employment in the sampled firms, the largest group $(80.8 \%)$ was the group of the firms in which the number of employees was below 50. The other option for total employment (50 and over) was pointed out as $19.2 \%$. Of these sampled firms, 76 SMEs (38.3\%) reported their activities in foreign markets while others $(61.7 \%)$ stated their positions as local firm.

\section{THE RESULTS}

An independent sample t-test was carried out on the mean scores of each individual item in order to understand whether significant differences existed between the mean scores assigned to the items by those in Greece versus those in Turkey. Table 1 reports that the viewpoint of Greek SMEs to 'taking risk for market success' appears to be more courageously ( $\mathrm{p}<$ 0.01). In comparison with those of Greek SMEs, Turkish SMEs' look to 'having a website to improve the market activities' was relatively negative $(\mathrm{p}<$ 0.05 ). The mean score of Turkish group in this item
(3.76) shows that an important part of the group has not just a strong view about a possible function of the internet for market process. However, it should be noted that 'the necessity of very close relationship with customers for firms' success' was ranked as the highest (4.20) by Turkish SMEs. These two rankings point out the situation of Turkish SMEs as having a tendency for traditional methods to maintain the relations with market although the internet offers a platform to build and manage close relationships with both prospective and available customers. There was no statistically significant difference between the groups in remaining items. However, the mean scores of Greek SMEs for entrepreneurial vision appear to be more consistent although they somewhat agree with the item of 'internet will be one of the most significant instrument of business' (3.57).

The findings of the comparison between Turkish and Greek SMEs stating their marketing philosophy are presented in the second part of Table 1. The largest difference was found in the statement of 'designing better programs than competitors for customer satisfaction is essential for us' $(p<0.001)$. Turkish SMEs exhibited more positive tendency than Greek SMEs in stating the thinking way to be essential. However, Greek SMEs had higher mean scores clearly than did Turkish SMEs for the item of 'our website is an instrument that supports our marketing strategies'

\section{Table 1: The Differences Between Turkish and Greek SMEs for Entrepreneurial Vision and Marketing Philosophy}

\begin{tabular}{|c|c|c|c|c|}
\hline & Turkish SMEs & Greek SMEs & & \\
\hline Entrepreneurial Vision & Mean & Mean & $\mathbf{t}$ & Sig. \\
\hline Necessary to develop new processes for market success & 4.05 & 4,12 & -.525 & 0.600 \\
\hline Availability of regular meetings to predict future rather than being a follower & 3.40 & 3.57 & -1.00 & 0.315 \\
\hline very close relationships with customers for firms' success & 4.20 & 4.07 & 0.954 & 0.341 \\
\hline The internet as one of the most significant instrument of business & 3.66 & 3.57 & 0.467 & 0.641 \\
\hline Traditional business methods with lower failure risk compared to new methods & 3.13 & 3.10 & 0.188 & 0.851 \\
\hline Inevitability of taking risk for market success & 3.21 & 3.71 & -2.923 & 0.004 \\
\hline Having a website to improve the market activities & 3.76 & 4.10 & -2.121 & $\mathbf{0 . 0 3 5}$ \\
\hline Not worth designing a website to reach market success & 2.52 & 2,22 & 1.461 & 0.146 \\
\hline
\end{tabular}

\begin{tabular}{|c|c|c|c|c|}
\hline Marketing Philiosophy & Mean & Mean & $\mathbf{t}$ & Sig. \\
\hline Not necessary to contact with customer from the 'globe' due to our limited resources & 2.83 & 2.62 & 1.049 & 0.295 \\
\hline Not need a special effort to explain our quality to customers due to proved quality & 2.45 & 2.32 & 0.750 & 0.454 \\
\hline Essential to design better programs than competitors for customer satisfaction & 4.28 & 3.82 & 3.543 & 0.000 \\
\hline Prior to create a supperior image in markets and customers' mind & 3.86 & 3.90 & -0.264 & 0.792 \\
\hline Customers from the 'globe' should access easily to our information & 3.84 & 3.78 & 0.348 & 0.728 \\
\hline Necessary to open to new methods related to marketing activities & 3.76 & 4.01 & -1.622 & 0.106 \\
\hline Prior task to improve and maintain the relationships with customers & 4.21 & 4.29 & -0.736 & 0.463 \\
\hline Our website is an instrument that supports our marketing strategies & 3.85 & 4.36 & -2.899 & 0.004 \\
\hline
\end{tabular}

Note: The negative t-values mean that Greek SMEs have higher mean scores than Turkish SMEs for the related items. The criteria were based on a five-point scale, ranging from $1=$ strongly disagree to $5=$ strongly agree. 
$(p<0.01)$. Although it is possible to evaluate that having a website supporting marketing strategies means the availability of efforts to design better activities, Turkish SMEs reflected less positive thought for this item.

The first part of Table 2 shows comparisons between the mean scores of Turkish and Greek SMEs based on their perceived ease of use for e-marketing activities.

Based on t-test results, the two groups were not significantly different in the perceptions towards ease of use of e-marketing activities, except only one namely 'it is easy to begin e-marketing' $(p<0.01)$. It should be noted that overall measures for 'perceived ease of use' reported Turkish SMEs with more positive perceptions, compared to Greek SMEs, that can be seen as a signal for more positive attitudes for emarketing.

Perceived usefulness by the sampled firms on emarketing's contributions throughout the firm processes was reported in the second part of Table 2 . The only significant difference was found in the perception towards a possible function of e-marketing 'to strengthen the image of the firm in marketplace' $(p<$ 0.05). Perceived usefulness by Greek SMEs appeared clearly stronger than Turkish group in terms of its reinforcing role on firm's image. The mean scores of remaining eight items did not show any significant difference $(p>0.05)$. This means that both SME groups had similar perceptions towards usefulness of e-marketing with positive tendencies although it is a fact that the possible function 'to decrease the cost of operations' was ranked as the lowest in both groups (3.30 and 3.23, respectively).

The comparisons between the mean scores of the sampled groups for attitude are reported in the third part of Table 2. According to findings the group of Greek SMEs obviously exhibited more positive tendency in reporting their evaluations. There are significant differences between Turkish and Greek SMEs, the former had less scores than the latter in overall measures except two items (Profitable -Not profitable; Convenient -Not convenient, $\mathrm{p}>0.05)$.

Table 2: The Differences Between Turkish and Greek SMEs for Perceived Ease of Use, Perceived Usefulness, and Attitude

\begin{tabular}{|c|c|c|c|c|}
\hline & Turkish SMEs & Greek SMEs & & \\
\hline Ease of Use & Mean & Mean & $\mathbf{t}$ & Sig. \\
\hline Easy to begin e-marketing activities & 3.91 & 3.39 & 2.966 & 0.004 \\
\hline Easy to learn how to operate e-marketing activities & 3.73 & 3.33 & 1.933 & 0.055 \\
\hline Easy to operate e-marketing activities & 3.35 & 3.28 & 0.314 & 0.754 \\
\hline Easy to become skillful on e-marketing & 3.27 & 3.05 & 1.102 & 0.272 \\
\hline
\end{tabular}

\begin{tabular}{|c|c|c|c|c|}
\hline Perceived Usefulness & Mean & Mean & $\mathbf{t}$ & Sig. \\
\hline Decreases the cost of operations & 3.30 & 3.23 & 0.327 & 0.744 \\
\hline Strengthens the ability to compete & 4.09 & 4.13 & -0.277 & 0.782 \\
\hline Improves the relationships with customers and suppliers & 3.94 & 4.15 & -1.309 & 0.192 \\
\hline Increases the effectiveness of distribution activities & 3.40 & 3.39 & 0.030 & 0.976 \\
\hline Creates "time utility" & 3.85 & 3.99 & -0.825 & 0.410 \\
\hline Permanent flow of information between the firm and market & 4.17 & 4.15 & 0.236 & 0.814 \\
\hline Makes the efforts to win a reliable identity for the firm easier & 3.76 & 3.50 & 1.500 & 0.135 \\
\hline Srengthens the image of the firm in marketplace & 3.67 & 4.06 & -2.176 & 0.031 \\
\hline Makes penetrating the new markets easier & 4.12 & 4.15 & -0.177 & 0.860 \\
\hline
\end{tabular}

\begin{tabular}{|c|c|c|c|c|}
\hline Attitude & Mean & Mean & $\mathbf{t}$ & Sig. \\
\hline Reliable- Not reliable & 4,50 & 5,09 & -2.464 & 0.015 \\
\hline Useful- Not useful & 5,86 & 6,27 & -2.307 & 0.022 \\
\hline Profitable -Not profitable & 4,91 & 4,95 & -0.146 & 0.884 \\
\hline Convincing - Not convincing & 4,75 & 5,59 & -3.522 & 0.001 \\
\hline Necessary - Not necessary & 5,35 & 6,17 & -3.525 & 0.001 \\
\hline Convenient -Not convenient & 5,47 & 5,37 & 0.401 & 0.689 \\
\hline
\end{tabular}

Note 1: The negative t-values mean that Greek SMEs have higher mean scores than Turkish SMEs for the related items. The criteria were based on a five-point scale, ranging from $1=$ strongly disagree to $5=$ strongly agree.

Note 2: The negative t-values mean that Greek SMEs have higher mean scores than Turkish SMEs for the related items. The criteria were based on semantic bipolar items, ranging from $1=$ reliable, useful , ... to $7=$ not reliable, not useful.... 
In order to assess the validity of the hypotheses developed in this study we used regression analysis. Separate regression analyses were run to exhibit the explanatory level of entrepreneurial vision, marketing philosophy and perceptions of SMEs for attitude towards e-marketing. Before doing the regression analyses we determined that no violations of the assumptions of regression were observed. Prior to running the regression analyses, a correlation test was applied to look for possible signs of multicollinearity. Correlations of variables were not high enough to be of concern for regression analysis. Although not reported here in a table, the greatest variance inflation factor (VIF) statistic in the model was 3.0, substantially less than the conservative cut-off of 10 suggested by Hair et al. (1998).

The results of the regression analyses for how predictive the constructs of entrepreneurial vision and marketing philosophy were are shown in Table 3. According to data in table 3 , the regression coefficients for marketing philosophy in both groups are statistically significant when $p<0.001$. This result supports our H1 hypothesis for both Turkish and Greek SMEs. The R square scores were 0.45 and 0.42 for Turkish

\section{Table 3 - The Results of Regression Analyses for H1 (Vision- Philosophy), H2 (Vision- Perceived Usefulness), H3 (Philosophy-Perceived Ease of Use)}

Hypothesis 1 (Vision- Philosophy)

\begin{tabular}{|c|c|c|c|c|c|c|c|c|}
\hline $\begin{array}{l}\text { Variable } \\
\text { in Model }\end{array}$ & $\begin{array}{r}\mathbf{B} \\
\text { Turkish }\end{array}$ & $\begin{array}{r}\text { B } \\
\text { Greek }\end{array}$ & $\begin{array}{r}\text { Std. } \\
\text { Error } \\
\text { Turkish }\end{array}$ & $\begin{array}{r}\text { Std. } \\
\text { Error } \\
\text { Greek }\end{array}$ & $\begin{array}{r}\text { Beta } \\
\text { Turkish }\end{array}$ & $\begin{array}{r}\text { Beta } \\
\text { Greek }\end{array}$ & $\begin{array}{r}\text { t } \\
\text { Turkish }\end{array}$ & $\begin{array}{r}\text { t } \\
\text { Greek }\end{array}$ \\
\hline (Constant) & 1.331 & 1.959 & 0.302 & 1.735 & & & & \\
\hline Vision & 0.656 & 0.479 & 0.085 & 0.514 & 0.675 & 0.655 & 8.435 & 8.011 \\
\hline Multiple R & 0.675 & 0.545 & & & & & & \\
\hline R Square & 0.456 & 0.297 & & & & & & \\
\hline Adjusted R & 0.449 & 0.292 & & & & & & \\
\hline Std. Error & 0.330 & 0.315 & & & & & & \\
\hline F-Value & $71,143 *$ & $64.170^{*}$ & & & & & & \\
\hline Observations & 116 & 82 & & & & & & \\
\hline
\end{tabular}

Note: *significance at the 0.001 level.

Hypothesis 2 (Vision - Perceived Usefulness )

\begin{tabular}{|c|c|c|c|c|c|c|c|c|}
\hline $\begin{array}{l}\text { Variable } \\
\text { in Model }\end{array}$ & $\begin{array}{r}\text { B } \\
\text { Turkish }\end{array}$ & $\begin{array}{r}\text { B } \\
\text { Greek }\end{array}$ & $\begin{array}{r}\text { Std. } \\
\text { Error } \\
\text { Turkish } \\
\end{array}$ & $\begin{array}{r}\text { Std. } \\
\text { Error } \\
\text { Greek }\end{array}$ & $\begin{array}{r}\text { Beta } \\
\text { Turkish }\end{array}$ & $\begin{array}{r}\text { Beta } \\
\text { Greek }\end{array}$ & Turkish & $\begin{array}{r}\text { t } \\
\text { Greek }\end{array}$ \\
\hline (Constant) & -0.160 & -0.207 & 0.302 & 0.357 & & & & \\
\hline Vision & 1.415 & 1.131 & 0.085 & 0.098 & 0.842 & 0.790 & 5.202 & 11.527 \\
\hline Multiple R & 0.842 & 0.790 & & & & & & \\
\hline R Square & 0.710 & 0.624 & & & & & & \\
\hline Adjusted R & 0.707 & 0.619 & & & & & & \\
\hline Std. Error & 0.516 & 0.471 & & & & & & \\
\hline F-Value & $278,668^{*}$ & $132.867^{*}$ & & & & & & \\
\hline Observations & 116 & 82 & & & & & & \\
\hline
\end{tabular}

Note: *significance at the 0.001 level.

Hypothesis 3 (Philosophy-Perceived Ease of Use)

\begin{tabular}{|c|c|c|c|c|c|c|c|c|}
\hline $\begin{array}{l}\text { Variable } \\
\text { in Model }\end{array}$ & $\begin{array}{r}\text { B } \\
\text { Turkish }\end{array}$ & $\begin{array}{r}\text { B } \\
\text { Greek }\end{array}$ & $\begin{array}{r}\text { Std. } \\
\text { Error } \\
\text { Turkish } \\
\end{array}$ & $\begin{array}{r}\text { Std. } \\
\text { Error } \\
\text { Greek }\end{array}$ & $\begin{array}{r}\text { Beta } \\
\text { Turkish }\end{array}$ & $\begin{array}{r}\text { Beta } \\
\text { Greek }\end{array}$ & Turkish & Greek \\
\hline (Constant) & 3.159 & $-2,454$ & 1.057 & 2.454 & & & & \\
\hline Philosophy & 0.180 & 1,532 & 0.275 & 1.532 & 0.487 & 0.346 & 4.798 & 2.970 \\
\hline Multiple R & 0.487 & 0.346 & & & & & & \\
\hline R Square & 0.237 & 0.119 & & & & & & \\
\hline Adjusted R & 0.227 & 0.106 & & & & & & \\
\hline Std. Error & 0.809 & 1.094 & & & & & & \\
\hline F-Value & 23.022 & $8.821^{*}$ & & & & & & \\
\hline Observations & 116 & 82 & & & & & & \\
\hline
\end{tabular}

Note: *represents significance at the 0.001 level. 
Table 4: The Results of Regression Analyses for H4 (Vision- Attitude), H5 (Philosophy - Attitude), H6 (Perceived Ease of Use- Attitude) and H7 (Perceived Usefulness-Attitude)

\begin{tabular}{|c|c|c|c|c|c|c|c|c|}
\hline Hypothesis 4 & $\begin{array}{r}\text { B } \\
\text { Turkish }\end{array}$ & $\begin{array}{r}\text { B } \\
\text { Greek }\end{array}$ & $\begin{array}{r}\text { Std. } \\
\text { Error } \\
\text { Turkish }\end{array}$ & $\begin{array}{r}\text { Std. } \\
\text { Error } \\
\text { Greek }\end{array}$ & $\begin{array}{r}\text { Beta } \\
\text { Turkish }\end{array}$ & $\begin{array}{r}\text { Beta } \\
\text { Greek }\end{array}$ & Turkish & $\begin{array}{r}\mathrm{t} \\
\text { Greek }\end{array}$ \\
\hline (Constant) & -2.403 & 0.015 & 0.536 & 0.535 & & & & \\
\hline Vision & 2.147 & 1.545 & 0.151 & 0.147 & 0.800 & 0.761 & 14.260 & 10.500 \\
\hline Multiple R & 0.800 & 0.761 & & & & & & \\
\hline R Square & 0.641 & 0.579 & & & & & & \\
\hline Adjusted R & 0.638 & 0.574 & & & & & & \\
\hline Std. Error & 0.916 & 0.706 & & & & & & \\
\hline F-Value & 203.353 & $110.246^{*}$ & & & & & & \\
\hline Observations & 116 & 82 & & & & & & \\
\hline
\end{tabular}

\begin{tabular}{|c|c|c|c|c|c|c|c|c|}
\hline Hypothesis 5 & $\begin{array}{r}\text { B } \\
\text { Turkish }\end{array}$ & $\begin{array}{r}\text { B } \\
\text { Greek }\end{array}$ & $\begin{array}{r}\text { Std. } \\
\text { Error } \\
\text { Turkish } \\
\end{array}$ & $\begin{array}{r}\text { Std. } \\
\text { Error } \\
\text { Greek }\end{array}$ & $\begin{array}{r}\text { Beta } \\
\text { Turkish }\end{array}$ & $\begin{array}{r}\text { Beta } \\
\text { Greek }\end{array}$ & $\begin{array}{r}\text { t } \\
\text { Turkish }\end{array}$ & $\begin{array}{r}\mathbf{t} \\
\text { Greek }\end{array}$ \\
\hline (Constant) & -0.349 & 1.741 & 0.851 & 0.316 & & & & \\
\hline Philosophy & 1.608 & 0.666 & 0.227 & 0.083 & 0.609 & 0.569 & 7.082 & 7.986 \\
\hline Multiple R & 0.609 & 0.569 & & & & & & \\
\hline R Square & 0.371 & 0.324 & & & & & & \\
\hline Adjusted R & 0.364 & 0.319 & & & & & & \\
\hline Std. Error & 0.937 & 0.368 & & & & & & \\
\hline F-Value & $50.155^{*}$ & $63.769^{*}$ & & & & & & \\
\hline Observations & 116 & 82 & & & & & & \\
\hline
\end{tabular}

\begin{tabular}{|c|c|c|c|c|c|c|c|c|}
\hline Hypothesis 6 & $\begin{array}{c}\text { B } \\
\text { Turkish }\end{array}$ & $\begin{array}{r}\text { B } \\
\text { Greek }\end{array}$ & $\begin{array}{r}\text { Std. } \\
\text { Error } \\
\text { Turkish } \\
\end{array}$ & $\begin{array}{r}\text { Std. } \\
\text { Error } \\
\text { Greek }\end{array}$ & $\begin{array}{r}\text { Beta } \\
\text { Turkish }\end{array}$ & $\begin{array}{r}\text { Beta } \\
\text { Greek }\end{array}$ & Turkish & $\begin{array}{r}\mathrm{t} \\
\text { Greek }\end{array}$ \\
\hline (Constant) & 3.223 & 5.602 & 0.259 & 5.602 & & & & \\
\hline Ease of Use & 0.733 & 0.129 & 0.067 & 0.129 & 0.785 & 0.307 & 10.883 & 2.604 \\
\hline Multiple R & 0.785 & 0.307 & & & & & & \\
\hline R Square & 0.615 & 0.094 & & & & & & \\
\hline Adjusted R & 0.610 & 0.081 & & & & & & \\
\hline Std. Error & 0.537 & 0.466 & & & & & & \\
\hline F-Value & $118.441^{*}$ & $6.782 * *$ & & & & & & \\
\hline Observations & 116 & 82 & & & & & & \\
\hline
\end{tabular}

\begin{tabular}{|c|c|c|c|c|c|c|c|c|}
\hline Hypothesis 6 & $\begin{array}{r}\text { B } \\
\text { Turkish }\end{array}$ & $\begin{array}{r}\text { B } \\
\text { Greek }\end{array}$ & $\begin{array}{r}\text { Std. } \\
\text { Error } \\
\text { Turkish } \\
\end{array}$ & $\begin{array}{r}\text { Std. } \\
\text { Error } \\
\text { Greek }\end{array}$ & $\begin{array}{r}\text { Beta } \\
\text { Turkish }\end{array}$ & $\begin{array}{r}\text { Beta } \\
\text { Greek }\end{array}$ & $\begin{array}{r}\text { t } \\
\text { Turkish }\end{array}$ & $\begin{array}{r}\mathbf{t} \\
\text { Greek }\end{array}$ \\
\hline (Constant) & -0.393 & 0.637 & 0.245 & 0.270 & & & & \\
\hline Perceived Usef & lness 1.452 & 1.278 & 0.062 & 0.069 & 0.909 & 0.901 & 23.313 & 18.614 \\
\hline Multiple R & 0.909 & 0.901 & & & & & & \\
\hline R Square & 0.827 & 0.812 & & & & & & \\
\hline Adjusted R & 0.825 & 0.810 & & & & & & \\
\hline Std. Error & 0.636 & 0.472 & & & & & & \\
\hline F-Value & 543.482 & $346.485^{*}$ & & & & & & \\
\hline Observations & 116 & 82 & & & & & & \\
\hline
\end{tabular}

Note: * represents significance at the 0.001 level $\quad * *$ represents significance at the 0.05 level 
and Greek SMEs respectively; about 45 and 42 percent of the variance in predicting the marketing philosophy could be explained by the items in this questionnaire. The beta values indicate that the dimension of entrepreneurial vision $(0.67,0.65$ respectively) made statistically positive and significant contribution on marketing philosophy. Thus, it is possible to state that marketing philosophy of SMEs is positively related to their entrepreneurial vision. In other words, when SMEs' entrepreneurial vision becomes broader, a tendency in their marketing philosophy will occur to market orientation that requires focusing on opportunities and threats for competitiveness. Emarketing activities can also be evaluated by SMEs in the context of new opportunities and challenges in marketplace. Then, marketing philosophy or thinking broader on market events will be shaped based on entrepreneurial vision of SMEs.

The second hypothesis (H2), which tested the association between entrepreneurial vision and perceived usefulness of e-marketing was also supported by our data for both groups. The higher scores of $\mathrm{R}$ square in each group ( 0.71 and 0.62 , respectively) show the strong influence of entrepreneurial vision on the perceptions of SMEs towards usefulness of emarketing. The beta values ( 0.84 and 0.79 , respectively) indicate that the vision made more positive and significant contribution on perceived usefulness in the sample of Turkish SMEs.

Our third hypothesis (H3) predicted that SMEs' perceived ease of use of e-marketing is positively related with their marketing philosophy. The data collected in this research supported the hypothesis in each group of SMEs separately although $\mathrm{R}$ squares were relatively lower ( 0.23 and 0.12 , respectively). As in the first two hypotheses, the beta value of Turkish group was higher than those of Greek $(0.48$ and 0.34 , respectively). According to the result of this hypothesis, when SMEs are enthusiastic to seek opportunities and become more competitive their perceived ease of use for e-marketing activities will change positively. That is, the more positive perceptions towards ease of use of e-marketing, the less difficulties to use e-marketing their evaluations.

The four constructs (entrepreneurial vision, marketing philosophy, perceived ease of use, and perceived usefulness) conceived in the model to explain the attitudes of SMEs to e-marketing were analyzed for how predictive they were of the construct of attitude. The results of a series of regression analyses are presented in table 4 .

The fourth hypothesis of the research expected a positive relationship between entrepreneurial vision and SMEs' attitudes towards e-marketing. This hypothesis was supported by our data. It was expected that as the SMEs have a broader vision they will build more positive attitude to e-marketing due to its possible function to create new market opportunities as well as utilize the existing ones. In line with our expectation the regression model was significant in each group (F-value: 203.35 and 110.24 respectively, $\mathrm{p}<0.001$ ).

Our next hypothesis (H5) was also supported by the data. The variable marketing philosophy had a positive and significant $(\mathrm{p}<0.001$ and 0.05 , respectively) coefficient. We expected in the context of this hypothesis that as the marketing philosophy of SMEs turns to market orientation so does the attitude towards e-marketing more positive. As argued in the conceptual section, market orientation of SMEs can make them more sensitive to competitiveness that requires being interested in new opportunities and challenges in market environment. However, the value of R square in both Turkish and Greek SMEs was relatively lower (37.1 and 32.4, respectively) among this group of hypotheses.

The sixth hypothesis (H6), which tested the association between perceived ease of use by SMEs and attitude towards e-marketing, was supported in each group although the significance level of the regression models for Turkish and Greek SMEs was different (F-value: 118.44, $\mathrm{p}<0.001$; F-value: 6.78, $\mathrm{p}<0.05$, respectively). Indeed, the R square of Greek SMEs was 0.09 as the lowest value in this group of hypotheses; about only 9 percent of the variance in predicting the construct of attitude could be explained by perceived ease of use in terms of Greek SMEs. However, in the sample of Turkish SMEs the value of R square (0.61) appeared to be satisfactory. Moreover the analysis showed that perceived ease of use ( $\beta: 0.78$ ) was an important determinant in Turkish SMEs on the attitude unlike Greek SMEs $(\beta: 0.30)$.

In our final hypothesis (H7), we had expected that perceived usefulness has a positive effect on the attitude towards e-marketing. The coefficient for perceived usefulness signed as predicted in our hypothesis with statistically significant $(p<0.001)$ providing very strong support for $\mathrm{H} 7$. Indeed, the beta values in each sampled group (0.91 and 0.90, respectively) indicate that perceived usefulness made the most statistically positive and significant contribution among the constructs of the model. 


\section{CONCLUSION}

Improvements in commmunication technologies, especially the internet, provide many opportunities to both larger-sized and small and medium-sized entreprises (SMEs) alike. SMEs are widely known as less competitive than those of larger-sized firms in market environment surrounded by severe competition. Reaching to competitive identity, therefore, is critically important for SMEs as well as larger firms. SMEs traditionally have lack of adequate resources for effective market operations such as not having a satisfactory budget to announcement what they do and what their unique features are. Hence, they have to limit their activities only to some accessible markets due to the main disadvantage in announcement, explanation and reaching to target markets. However, the progress of the internet means for SMEs a valuable instrument to remove these traditional disadvantages. By using the instrument effectively, SMEs can easily reach to millions of customers representing many opportunities in competitive market environment. In order for SMEs to realize the potential of the internet in market processess, the owners or top managers who are decision-makers in SMEs should primarily be aware of the advantages suggested by e-marketing. More spesifically, the decision-makers of SMEs should have positive attitudes towards e-marketing initially. It is possible to mention that opportunity perceptions are closely related to the vision of SMEs since the vision is defined as broader viewpoint to the happenings. Also, marketing philosophy can be expected to influence the way of thinking on market opportunities and threats.

In this cross-cultural study, we analyzed attitudes of SMEs towards e-marketing. At the same time the possible determinants suggested in the literature on attitude were also examined since a general attitude is similar to values in that it is embedded in our minds to influence our thoughts of a specific object or phenomenon (Bredahl, 2001). Thus, the direction of attitude can be an important indicator to understand behaviors. More specifically, attitude or internal view can be expected to play a leading role in behaviors, since feelings, beliefs and evaluations can also influence subsequent processing. We examined the data in a comparison of Turkish and Greek SMEs to determine the similarities and differences between SMEs from the two neighbouring countries. Statistical analyses executed in this study showed that both of the groups exhibited similarities in most of the constructs. Nevertheless, Greek SMEs have appeared with more positive attitudes towards e-marketing than Turkish SMEs while the proposed determinants influenced the attitude for the group of Turkish SMEs in a relatively stronger way.

While there are many academical attempts on SMEs' reactions to the internet, there exists a research gap on the atttitudes of SMEs directly. And also there appears a lack of cross-cultural study examining this aspect. By providing empirical data concerning Turkish and Greek SMEs' attitudes towards e-marketing, this study tries to contribute to filling the mentioned research gap. While findings of this study are limited to a small group of Turkish and Greek SMEs, they could also have relevance for the other huge group of SMEs with similar characteristics. 


\section{REFERENCES}

Adams, D.A., Nelson, R.R. and Todd, P.A.(1992), Perceived usefulness, ease of use, and usage of information technology: a replication, MIS Quarterly (June 1992), pp. 227-247.

Ajzen, I. and Fishbein, M. (1980), Understanding Attitudes and Predicting Social Behavior. PrenticeHall, Englewood Cliffs, NJ.

Avlonitis G. and Karayanni D. (2000), The impact of Internet use on business-to business marketing, Industrial Marketing Management, 29, pp. 441- 59.

Bartels, R. (1988), The History of Marketing Thought. Columbus: Publishing Horizons.

Bird, B. J. and Brush, C. G. (2003), Exploring leadership vision:New perspectives on women entrepreneurs and executives. In J. Butler (Ed.), Research in entrepreneurship and management: Special issue on women entrepreneurs:51?69. Charlotte, NC: Information Age Publishing.

Bredahl, L. (2001), Determinants of consumers attitudes and purchase intentions with regards to genetically modified foods - results of a cross-national survey, Journal of Consumer Policy 24, 23-61.

Brush, C.G. (2008), Pionerring Strategies for Entrepreneurial Succes, Business Horizons, 51, pp. 21-27.

Chaston, I. (2001), The Internet and E-Commerce: An Oppurtunity to Examine Organisational Learning in Progress in Small Manufacturing Firms?, International Small Business Journal, 19 (2), pp. 1320.

Covey, S. R. (2004), The 7 habits of highly effective people. NewYork: Free Press.

Davis, F.D., (1989), Perceived usefulness, perceived ease of use, and user acceptance of information technology, MIS Quarterly, (September), pp. 319340 .

Drew, S. (2003), Strategic Uses of E-Commerce by SMEs in the East of England, European Management Journal, 21 (1), pp. 79-88.

Fortin D. R, Dholakia R. R. and Dholakia, N. (2002), Emerging issues in electronic marketing: thinking outside the square, Journal of Business Research, Volume 55, Issue 8, (August), pp. 623-627.

Fishbein, M., (1963), An investigation of the relationships between beliefs about an object and the attitude toward that object, Human Relations 16: 233240 .
Grunert, K.G., Lahteenmaki, L., Nielsen, N.A., Poulsen, J.B., Ueland, O., Astrom, A., (2001), Consumers perceptions of food products involving genetic modification - results from a qualitative study in four nordic countries, Food Quality and Preferences 12 , pp. 527-542.

Hair, J. F., Bush, R.P. and Ortinau, D. J. (2000), Marketiing Research: A Practical Approach for the New Millenium. Singapore: McGraw-Hill Higher Education.

Hendrickson, A.R., Massey, P.D. and Cronan, T.P.(1993), On the testretest reliability of perceived usefulness and perceived ease of use scales, MIS Quarterly (June 1993), pp. 227-230.

Hinkin, T. R., Tracey, J. B. and Enz, C. A. (1997), Scale construction: Developing reliable and valid measurement instruments, Journal of Hospitality and Tourism Research, 21(1), pp. 100-120.

Honeycutt E, Fluherty T, Benassi K. (1998), Marketing industrial products on the Internet, Industrial Marketing Management, 27, pp. 63 - 72.

Menon, A. and Varadarajan, R. (1992), A model of marketing knowledge use within firms, Journal of Marketing, 56, pp. 53-71.

Kathryn M. Kimery and Shelley M. Rinehart Markets and Constituencies: An Alternative View of the Marketing Concept, Journal of Business Research, 43, pp. 117-124.

Kohli, A. and Jaworski, B. (1990): Market Orientation: The Construct, Research Propositions, and Managerial Implications, Journal of Ma keting, 54 (April), pp. $1-18$.

Krishnamurthy, S. (2006), Introducing e-markplan: A practical methodology to plan e-marketing activities, Business Horizons, 49, pp. 51-60.

Lamb, C., Hair J. and McDaniel C. (2004), Essentials of Marketing. Cincinnati: South-Western Publishing.

Lee, B.C.Y. (2007), Consumer attitude toward virtual stores and its correlates, Journal of Retailing and Consumer Services, 14, pp. 182-191.

Lewis, R. C. (1984), Theoretical and practical considerations in research design. Cornell Hotel and Restaurant Administration Quarterly : 25-35.

Lieberman, M. B. and Montgomery, D. B. (1988), First-mover advantages, Strategic Management Journal, 9(5), pp. 41 ?58.

Merrit, J.Q. (1998), EM into SME won't go: attitudes, awareness and practices in the London 
Borough of Croydon, Business Strategy and the Environment, 7, pp. 90-100.

Morgan, R. (1996), Conceptual Foundations of Marketing and Marketing Theory, Management Decision 34(10), pp. 19-26.

Montserrat C, Gil J. M., Traill, W. B. (2008), Consumer acceptance, valuation of and attitudes towards genetically modified food: Review and implications for food policy, Food Policy 33 , pp. 99-111.

Narver, J. and Slater, S.(1990), The Effect of a Market Orientation on Business Profitability. Journal of Marketing, (October), pp. 20-35.

Ngai, E.W.T. and Wat, F.K.T. (2002), A literature review and classification of electronic commerce research, Information and Management 39, pp. 415429.

OECD (Organization for Economic Cooperation and Development) 1998, SMEs and electronic commerce. Paris.

Ryan, T. A. (1970), Intentional behavior. New York: Ronald Press.

Senge, P. (1990), The fifth discipline: The Art and Practice of the Learning Organization. New York: Doubleday Currency Publishing.

Slater, S. and Narver, J. (1994), Does Competitive Environment Moderate the Market OrientationPerformance Relationship? Journal of Marketing 58 (January), pp. 46-55.

Smith, M.A. and Kemp, R.(1998), Small Firms and the Environment: A Grounded Report.

Groundwork, Birmingham.

Stayman, D.M., Batra, R. (1991), Encoding and retrival of ad affect in memory, Journal of

Marketing Research, 28 (3), pp. 232-239.

Strange, J.M. and Mumford, M.D.,(2005), The origins of vision: Effects of ref lection, models, and analysis, The Leadership Quarterly 16, pp. 121-148.

Subramanian, G.H.(1998), A replication of perceived usefulness and perceived ease of use measurement, Decision Science 25 (5-6) , pp. 863-874.

Tinsley, H. O. and Tinsley, D. (1987), Uses of factor analysis in counselling psychology research, Journal of Counselling Psychology, 34, pp. 414-424.

Tosun, C., Okumus F. and Fyall, A., Marketing Philosophies, Annals of Tourism Research, Vol. 35, (1), pp. 127-147.
Webb, B. and Sayer, R. (1998), Benchmarking Small Companies on the Internet, Long Range Planning, 31 (6), pp. 815-827.

Wilkie, W.L. (1994), Consumer Behavior, third ed. Wiley, NY, pp. 280-282. 